\title{
Interstitial Power in Fields of Limited Statehood: Introducing a "Weak Field" Approach to the Study of Transnational Settings
}

\author{
Antoine Vauchez \\ Centre National de la Recherche Scientifique/Université Paris 1 Panthéon-Sorbonne
}

How does field theory unfold at the transnational level? How tailored is it to weakly differentiated international settings featured by limited statehood? By raising such questions, I do not wish to echo the analyses of those who consider that Pierre Bourdieu's work as quintessentially "franco-centric" and, as such, incapable of producing fruitful research hypotheses beyond its initial context of emergence. As Loïc Wacquant has argued in his foreword to the English edition of The State Nobility, questioning in terms of "field of power" offers "a systematic research program on any national field of power provided that the American (British, Japanese, Brazilian, etc.) reader carries out the work of transposition" (Wacquant in Bourdieu 1996[1989]). In fact, the large range of usages of Bourdieu's theoretical toolbox suffices to prove its value when applied to or confronted with other cultures or other time periods. It may even be argued that such heuristic qualities are particularly relevant to the study of international affairs. Here, more than in any other research domain, there is a need to consider power relations beyond the political and administrative sites of command and to consider the wider set of competing institutions, professions, and resources in which power (forms of domination and types of legitimacy) is defined and actually operates. Here more than in any other research domain, there is a need to counter the effects of disembodied historical accounts of reified collectives ("states," "NGOs," "international courts," "experts," "politicians," "civil servants") colliding with one another. As field theory populates these institutions with competing actors and tracks their socialization, personal trajectories, and professional careers, it proves particularly suited to unveil transnational and cross-sector circulation of ideas and models. As such, it is a powerful research device when it comes to tracing the socio-genesis of transnational institutions and groups as well as the power relations in which they are embedded.

Yet transplanting field theory to international settings may prove to be a risky endeavor. One reason for cautiousness lies in the fact that Bourdieu himself hardly ever engaged in such an adventurous undertaking. Even in his article on the "international circulation of ideas" (1999), he essentially focused on processes of "import" and "export" of authors and theories from one national academic field ("field of origin") to another ("field of reception"), without paying any particular attention to the relatively structured set of international professional associations, transnational disciplinary struggles, academic careers, and specific blend of cosmopolitan capital that may exert some influence in such process of transfer (Dezalay and Garth 2002; Madsen 2006; Heilbron, Guilhot, and Jeanpierre 2008; Bigo 2011, in this issue). However, the difficulty in transplanting "field theory" may be more profound insofar as it is deeply embedded in a more general narrative of state-building processes. This embeddedness is particularly clear in The State Nobility (1996 [1989]) and even more precisely in an article entitled "The Genesis of the Bureaucratic Field" (1994). In both 
publications, Bourdieu links the formation of European states as autonomous centers of political and bureaucratic command to the building of relatively autonomous (cultural, academic, bureaucratic, and legal) fields of contention. Among these, the legal field is probably the most emblematic case, if not the template that other sector-specific undertakings have in turn followed in their institutionalization strategies (Malatesta 2006). Its emergence as a autonomous field of contention is the by-product of the tight connection between the recognition of the State's authority over people and goods (through its specific legal and judicial power), on the one hand, and the production of legal categories of legitimacy (conceptually unifying territory, population, and sovereignty under the general concept of "State") by a specific group of specialized legal professionals, on the other. As a result, most social fields owe much of their autonomous settlement to their being grounded in the State's jurisdiction through nation-wide and state-sanctioned professional monopolies (university certification; professional licensing).

\section{Fields of Limited Statehood ${ }^{6}$}

When it comes to building a research strategy for the study of international settings, such narrative (according to which state-building and field autonomization are tightly coupled) may be misleading. This is not to deny the fruitfulness of comparing international/regional political undertakings (e.g., the European integration) and national state-building ${ }^{7}$; if nothing else because the former have been built by diplomats and lawyers that repeatedly drew on state knowledge and models. However, it is important to point to the potential risks of such state-building perspectives: in particular, the developmentalist bias that views international areas of practice in light of what they are purported to become (state-anchored and highly autonomized social fields), that is, as a mere transitory stage in a long process of autonomization/normalization toward national ideal types of relatively independent and strictly bounded fields. I argue that such analytical lenses (in terms of autonomization processes) obscure the lasting specificity of international settings that are featured by limited statehood and a weakly differentiated social structure.

Perhaps the best way to advocate for such a change in focus is to consider what is arguably the most advanced international state undertaking, namely the European Union. As a matter of fact, a variety of empirical studies evidence that the decades-long efforts of the European Union at promoting professional projects of continental dimensions have repeatedly failed in their attempt to undermine national professional jurisdictions. This is not to say that there has not been a sustained process of specialization around European Union-implicated professional activities paralleling the development of EU policies (Georgakakis and Weisbein 2010). However, such specialization patterns cannot be equated with an overall process of autonomization. First of all, even after decades of intensive political and economic integration, all sorts of European Union-related social fields remain deeply structured by a quasi-diplomatic logic of geographic balance, including the most integrated domains and institutions of Europe, such as the European Court of Justice (Cohen 2010) or the European Central Bank (Lebaron 2010). Second, national professions have so far resisted the centralizing effect of EU integration (Olgiati 2008). Even though professions had to engage a

\footnotetext{
${ }^{6}$ On the notion of "limited statehood," see Risse (2011).

${ }^{7}$ In the case of the European Union, for instance, such comparison with State formation allows to overcome the whole sui generis discourse that takes Europe's idiosyncratic architecture and "power formula" as a starting point or as a natural given, rather than considering it as a particular historical outcome of an ongoing struggle between competing professional groups over the forms and the scope of EU public authority (see Marks 1997).
} 
"defensive modernization" to EU market-oriented values, they have not lost their control over "the production of producers." Even in the case of EU law, arguably the most federal and integrated area of European construction, there is no such thing as $a$ European legal education or European bar examinations (De Witte 2008). It could even be argued that the European Union has actually contributed to reinforcing national professional bodies as the primary level of regulation. Certainly, the best example here is the development of the "mutual recognition" technique (as opposed to the traditional harmonization approach) in the case of Higher Education Diplomas (1989 Directive) which had the effect of "mutually interlocking" the country-specific regulation of university certification and professional licenses.

On the whole, then, even what is arguably the most advanced international state undertaking, namely the EU polity, does not hold by itself through a sort of endogenous and self-referential logics; rather, it is deeply embedded in highly institutionalized and differentiated national fields of power that exert a differential hold through a variety of social processes (socialization, valued credentials, career paths, established models of professional excellency, and so on). ${ }^{8}$ As they keep an interstitial positions in-between deep-seated national settings and their established constellation of elites, educational breeding grounds, or pathways to professional prestige, international settings are best understood as "transnational fields."

\section{Transnational Fields as "Weak Fields"}

My contention is that transnational fields have a perennially hybrid structure. As a matter of fact, they entail elements of both "settled" fields and "emerging" ones (Steinmetz 2008) without falling into either. Just like the latter, they remain deeply interwoven with neighboring fields and rather undifferentiated internally; just like the former, they are characterized by densely institutionalized settings populated by established transnational professionals competing upon a commonly valued type of symbolic capital. Such a compound structure reveals the necessity to reframe our analytical toolbox. Drawing from Christian Topalov's study of the field of "social reform" in late 19th-century France, I thus suggest that we treat transnational fields as "weak fields." Such an approach takes seriously the extensive interdependence and overlap of transnational settings with its neighboring fields. "Weakness" refers here to their interstitial position as they are merged into "other fields that are mapped out and constituted more firmly" (Topalov 1994:464; Vauchez 2008) as well as to the related blurriness and indifferentiation of their internal boundaries. In keeping with the general invitation of Bourdieu to use field theory as a heuristic toolbox, the purpose here is not to find "weak fields" or establish in a positivistic manner whether this or that social setting constitutes an authentic "weak field," but rather to assess in which measure a given field meets these two elements and how this is helpful in generating new sets of hypotheses in the study of given social processes.

\section{A Case Study: The Scholarly Construction of Europe}

In order to provide an empirical test of the added value of such "weak field" approach, let me consider one particular empirical puzzle: the pervasive presence in the European political agenda of watchwords that have been

\footnotetext{
${ }^{8}$ Prolonging such empirical evidences, Didier Georgakakis (2010) has pointed to the fact the "field of Eurocracy" has along a compound structure where "permanents" (from EU professionals to civil servants) coexist with "part timers" (from high-level national politicians to large companies' lobbyists or US-based law firms, etc.), the latter often holding more weight in the decision process than the former.
} 
produced or coproduced within the field of EU studies (such as the "European Constitution," "EU Governance," and the "Open Method of Coordination"). This puzzle grows even bigger if one considers that, despite the sixty years of intensive political and economic integration, the EU field of academic knowledge has remained loosely structured and poorly autonomized. True enough, the creation of separate chairs, journals, and book series in the domain of EU studies has pushed for a growing level of abstraction and stronger methodological requirements, thereby increasing the cost of entry one has to pay to authoritatively intervene in European Union-related scholarly debates. However, many indicators exemplify the perennial weakness of such fields: the paucity of supranational centers of academic certification (Collège de Bruges, European University Institute) vis-a-vis state-anchored disciplines and universities; the unusually high share of non-academics (legal practitioners, EU officials, and politicians) in academic settings (journals and congresses); the equally high proportion of scholars and PhD holders among EU political elites (Cohen 2010); the particular value granted to applied knowledge among EU-implicated scholars; and, relatedly, the specific mode of capitalization of academic authority which value not only scientific achievements but also expert positions and political influence. All in all, Euro-scholarship and the Euro-polity are not mutually exclusive entities but rather are characterized by a deep and enduring overlap. How is it, then, that the field of EU studies can participate to shape categories and norms in such a seemingly influential manner when it has such a low degree of autonomy and keeps such permeable boundaries?

My general hypothesis here is that such weakness is what renders EU transnational field particularly influential when it comes to shaping EU government's cognitive and normative frames (Mudge and Vauchez 2010; Robert and Vauchez 2010). In other words, I submit that the EU transnational academic field has an interstitial or brokering capacity that proves essential when looking at a polity-that of the European Union-generally considered as lacking cross-sectoral arenas. First of all, such permeable boundaries with the many (national or transnational) neighboring fields constitute a favorable context for multipositional entrepreneurs engaged in both theory-building and agenda-setting strategies (Cohen 2010). As they circulate across sectors and play on both parts of the academic and political fence, they are able to contribute to often unnoticed forms of policy alignment and synchronization across otherwise segmented, if not antagonistic, fields. Second, such a loosely structured field implies that the ageold sites of academic mobilization ("congresses," "journals," and "learned societies") are substantially different from what they refer to at the national level in highly autonomized and segmented academic fields. By many standards, their international counterparts are more akin to the first Sociétés savantes of the late 19th century, such as the American Social Science Association (1867) or the International Law Institute (1873), where ministers, statesmen, high civil servants, experts, and academics would meet and mobilize. As a result, they are at one and the same time an academic arena where renewed instruments of knowledge are built; a crossroads for exchanges and competitions among scholarly, economic, bureaucratic and political elites under the guise of discussing "current issues of EU rule of law" or of "EU economics"; and, last but not least, a mobilization device through which a diverse set of law-endowed (or economicsendowed) professionals in favor of a given political agenda ("establishing a European Constitution," a "Charter of Fundamental rights," or "re-launching the Single Market agenda"). As a result, the traditional borders between "science" and "reform" are largely blurred: the most integrated participants can successively wear the mantle of scholarship (promoting a higher level of abstraction and rationality), expertise (forging new rationales and ad hoc tools for international government), and professional practice (directly testing them in 
various policy fields). Porous and overlapping with bureaucratic, economic, legal, and political spaces, the field of EU studies therefore appears as an essential site of coordination and homogenization of commons frames of understanding Europe's nature and future.

On the whole, then, such perspective is essential not only for understanding the genesis of specific policy agendas, but also for grasping how a given portfolio resources (from within and outside academia) is pooled under their aegis, thereby shedding a new light on the differential trajectories of European policy frames. Thereby, the constitutive capacity of "weak fields" is not unconditional: their inbetween-ness is not automatically conducive to such cumulative pooling of resources. Whether forms of transnational capitalization of resources actually occur and to which extent it does is a matter of empirical research. In other words, the "weak field" approach does not imply any sort of "necessary" social effect ("strong" or "weak": on this point, see Dezalay 2011). Its main added value lies in the fact that it redirects the researcher's gaze toward forms and sites of unnoticed cognitive coordination and resource pooling that are made possible by the interstitial positioning of transnational fields.

\section{References}

Bigo, Didier. (2011) Pierre Bourdieu and International Relations: Power of Practices, Practices of Power. International Political Sociology 5 (3): 225-258.

Bourdieu, Pierre. (1994) Rethinking the State: Genesis and Structure of the Bureaucratic Field. Sociological Theory 12 (1): 2-18.

Bourdieu, Pierre. (1996 [1989]) The State Nobility: Elite Schools in the Field of Power. Stanford: Stanford University Press.

Bourdieu, Pierre. (1999) The Social Conditions of the International Circulations of Ideas. In A Critical Reader, edited by Richard Shusterman. London: Blackwell.

Cohen, Antonin. (2010) Legal Professionals or Political Entrepreneurs? Constitution Making as a Process of Social Construction and Political Mobilization. International Political Sociology 4 (2): 107-123.

De Witte, Bruno (2008) European Union Law: A Unified Academic Discipline?, EUI Working Paper RSCAS 2008/34.

Dezalay, Yves. (2011 forthcoming) Opportunities and Limits of a Weak Field. Lawyers and the Genesis of a Field of European Economic Power. In Lawyering Europe. EU Law as a Social Field, edited by Bruno de Witte, and Antoine Vauchez. London: Hart.

Dezalay, Yves, and Bryant Garth. (2002) The Internationalization of Palace Wars. Lawyers, Economists and the Contest for Latin America States. Chicago: Chicago University Press.

Georgakakis, Didier. (2010) Tensions Within Eurocracy? A Socio-morphological View. French Politics 8 (2): 116-144.

Georgakakis, Didier, and Julien Weisbein. (2010) From Above and from Below: A Political Sociology of European Actors. Comparative European Politics 8 (1): 93-109.

Heilbron, Johan, Nicolas Guilhot, and Laurent Jeanpierre. (2008) Toward a Transnational History of Social Sciences. Journal of the History of Behavioral Social Sciences 44 (2): 146-160.

Lebaron, Frederic. (2010) European Central Bank Leaders in the Global Space of Central Bankers. French Politics 8 (3): 294-320.

Madsen, Mikael R. (2006) Transnational Fields. Elements of a Reflexive Sociology of the Internationalization of Law. Retfaerd 3 (114): 23-41.

Malatesta, Maria. (2006) Professioni e gentiluomini. Storia delle professioni nell'Europa contemporanea. Turin: Einaudi.

Marks, Gary. (1997) A Third Lens. Comparing European Integration and State Building. In European Integration in Social Historical Perspective, edited by Jytte Klausen, and Louise Tilly. Lanham, MD: Rowman \& Littlefield.

Mudge, Stephanie Lee, And Antoine Vauchez. (2010) European Integration as Palace War. Law, Economics, and the Scholarly Construction of Europe. Paper Presented at the Council for the European Studies, Montreal, April 15-17 (on file with the author).

Olgiati, Vittorio. (2008) The European Learned Professions and the EU Higher Education Project. European Societies 10 (4): 545-565. 
Risse, Thomas, Ed. (2011) Governance Without a State: Politics and Policies in Fields of Limited Statehood. New York: Columbia University Press.

Robert, Cecile, and Antoine Vauchez. (2010) L'Académie européenne. Savoirs, experts et savants dans le gouvernement de l'Europe. Politix (89): 9-34.

Steinmetz, George. (2008) The Colonial States as a Social Field. American Sociological Review 73 (4): 589-612.

Topalov, Christian. (1994) Le Champ réformateur. In Laboratoire du Nouveau Siècle. La nebuleuse réformatrice et ses réseaux en France, 1880-1914, edited by C. Topalov. Paris: EHESS.

Vauchez, Antoine. (2008) The Force of a Weak Field: Law and Lawyers in the Government of the European Union. International Political Sociology 2 (2): 128-144. 